\title{
ARSON AND PSYCHIATRY
}

\section{Shavindra R. Dias, *Jayan Mendis \\ Department of Psychiatry \\ Faculty of Medicine, University of Peradeniya \\ * National Institute of Psychiatry, Angoda \\ Sri Lanka}

Fire, one of the four mighty elements of life, along with earth, air, and water, has long been one of the most destructive, fascinating, and useable forces for those who would wreak havoc on the lives of others. A pervasive and significant public health problem for many families, arsonrelated fires cause the loss of lives, suffer burns and injuries as a result of these crimes.

Fire setting (Arson) by adult psychiatric patients is a symptom found in many primary disorders. It is rarely a reflection of the classic disorder, pyromania, as historically defined. ${ }^{1}$ Arson is a major source of property damage, injury and death. Many people who commit arson have extensive psychiatric histories and symptoms at the time of their fire-setting. ${ }^{2}$. There are fire setters who are free from psychiatric illnesses, stars fire for financial reasons and as revenge as well. Here we report two cases where arson is seen in the context of inward psychiatric care.

\section{Case one}

A nineteen-year-old young man, ex-army person, presented with a history of destroying ones kitchen, and his belongings, without any apparent reason by fire. He has a history of Cannabis abuse for two years and alcohol abuse for the similar period, had a stress related to the refusal of his romantic proposition.

He believed firmly that his persecutors had done a malevolent charm, and made him consume Kabara* oil to make his destruction. As a remedy, the patient had burned coconut shells and had been inhaling the fumes. He believed that fumes will cause the oil to be excreted with his sweat. He burned towels, as he believed that this would prevent the Kabaras to come to his village and prevent the villages from extracting more Kabara oil from these alligators and further making him to consume. He used kerosene oil to burn his kitchen and did not give any explanation for this specific act, but laughed. When questioned, indicated some unspoken rationale. This amounts to a bizarre delusion. He also believed that twinkling of stares indicated that his girlfriend is in communication with him suggesting a delusional perception. He believed that his thought were known to others suggesting thought broadcast.

Due to his bizarre delusions delusional perception and delusion of thought broadcast, we could diagnose him as Schizophrenia. His persecutory delusions indicated him of having paranoid Schizophrenia.

\section{Case Two}

Fifty years old housewife, a diagnosed patient with paranoid Schizophrenia, burnt two houses, was suspicious and found wondering away from home. Her compliance was poor for medication.

She had been hearing voices from the walls of the houses. She also believes that there 
are cameras hidden inside these walls, which broadcast her behaviour to others. Due to these beliefs she had burned two houses by actively putting kerosene and burning them down. As the owners knew her illness, she had not been taken to police, but brought to hospital. She was diagnosed to have a relapse of Schizophrenia.

\section{Discussion}

Progress in the understanding of individuals who commit arson has been a slow but steady course over the past two decades. Broadly, causes for arson include, psychotic illness, learning disability, alcohol abusing, and mood-disordered and juvenile conduct disorder. ${ }^{3}$ There are clinical-legal relevance of this condition.

Fire setting in childhood and adolescence is associated with the more severe end of the conduct-disorder continuum and is considered to be poorer prognostic of later pathology. ${ }^{4}$

There are other causes for juvenile fire setters such as schizophrenia, organic mental disorder, posttraumatic stress disorder and severe mental retardation in this age group. There are rare cases reported as temporal lobe epilepsy with the involvement of the amygdala to explain arson in children ${ }^{5}$

A study examining mental health records and/or prison files of 283 adult arsonists revealed $90 \%$ of arsonists had recorded mental health histories. Of those $36 \%$ had the major mental illness such as schizophrenia or bipolar disorder while $64 \%$ were abusing alcohol or drugs at the time of their fire setting. Pyromania was only diagnosed in $1 \%$ of the cases. Different motives for setting fire included being angry and delusional. ${ }^{2}$

Both cases reported here were diagnosed as schizophrenia. They both committed arson under a delusional mind. These patients pose a risk to the society and self and hence were treated at a secure unit. Both patients gained full recovery on antipsychotics medication. They both could not remember the act of arson. This could be seen as repression, a psychological defense mechanism, operating to reduce the anxiety, associated with such destructive act.

There are forensic implications of their acts of arson. For both patients Mc Nortonôs rules could be applied, which states that his act is rational, taking into account of his delusional system and prove the absence of menssria (the guilty mind) ${ }^{7}$

They could be defended by the legal provision of ñunsound mindòat the time of offence. This states that patient was laboring under such a defect of reason, from the disease of the mind, as not to know the nature and the quality of the act he was doing, or, if he did know it that he did not know what he was doing was wrong. ${ }^{9}$

In a longitudinal study revealed that $4 \%$ were re-convicts of arson. ${ }^{8}$ Half of them were convicted of other crimes. An important guideline is that a person convicted of arson a second time is at a greater risk of further offences. ${ }^{8}$ Antisocial personality disorder, mental retardation persistent social isolation evidence that fire setting was done as a sexual gratification increases the risk of repeating the act.

Arson involves the destruction of property. Under such circumstances if the property has been insured against fire destructing one might expect the insurance company to pay you the damage. Ironically if the act is categorized as arson, then in most parts of the world one cannot claim the damage.

This should not be seen as medicalising a social problem. . There are fire setters who are free from psychiatric illnesses, stars fire for financial reasons and as revenge. They are refereed as ñMotivated Arsonò and should be denied the legal providence as stated above. 


\section{References}

1. Geller JL. Firesetting in the adult psychiatric population. Hosp Community Psychiatry. 1987 May;38 (5):501-6.

2. Ritchie EC, Huff TG. Psychiatric aspects of arsonists. J Forensic Sci. 1999 Jul;44 (4): 733-40.

3. Leong GB, Silva JA. Revisiting arson from an outpatient forensic perspective. J Forensic Sci. 1999 May;44(3):558-63.

4. Moore JM, Thompson-Pope SK, MMPI-A profiles of adolescent boys with a history of fire setting. J Pers Assess. 1996 Aug;67(1):116-26.
5. Pontius AA. Motiveless fire setting: implicating partial limbic seizure kindling by revived memories of fires in "Limbic Psychotic Trigger Reaction". Percept Mot Skills. 1999 Jun;88 (3 Pt 1): 970-82.

6. West D.(1965)murder followed by suicide Heinemann, London

7. Soot hill, K.L. and Pope ,P.J. (1973) Medicine science and law13,127-38.

8. Penal code 